\title{
SOME CONSIDERATIONS ON THE EXPRESSION "LOCO FILIAE" IN GAIUS' INSTITUTES
}

\section{Carlos Felipe Amunátegui Perelló* \\ Patricio-Ignacio Carvajal Ramírez**}

Key words: Manus; potestas; mancipium; Gaius

\section{Introduction}

The expression "loco filiae" that Gaius uses to describe the position of the wife in manu has led a significant number of scholars to the firm belief that manus and patria

* Professor of Roman law, Pontificia Universidad Católica, Chile. This article is part of the Conicyt Research Project Anillos de Instigación Asociativa SOC 1111 and Fondecyt Regular 1141231.

** Professor of Roman law, Pontificia Universidad Católica, Chile. This article is part of the Conicyt Research Project Anillos de Instigación Asociativa SOC 1111 and Fondecyt Regular 1141231. 
potestas were equivalent powers. ${ }^{1}$ Although the personal powers that a paterfamilias could exert over his descendants did not seem to match those that he could apply to his wife in manu, Gaius consistently uses the expression loco filiae to describe her position. The personal powers which a paterfamilias usually held in relation to his descendants, namely the vitae necisque potestas (the power to kill or let live), ius noxa dandi (the right to surrender the perpetrator of some pre-defined offences), and the ius vendendi (the right to sell them in mancipio), seem to have adjusted poorly to the position of a wife under manus. Although the possibility has been put forward that the husband had some kind of ius vitae necisque over his wife in $m a n u,{ }^{2}$ this notion remains controversial. ${ }^{3}$ Further, the possibility of selling one's own wife or surrendering her after a noxal action is not supported by any ancient sources. Therefore, if the wife under manus was not subject to the entire power that patria potestas grants, one may wonder what Gaius means by the expression "loco filiae" when he describes her position. In this article we will systematically analyse the texts where Gaius mentions the position of a wife in manu and compare it with the position of other persons alieno iuri subiectae - the son, the slave and the son in mancipio - who were subject to the other personal powers that the pater held (potestas over his sons and slaves and mancipium over the sons of other patres whom he acquired through mancipatio).

1 The matter has been under discussion for over a century. The discussion began when Gans, after a difficult philological examination, stated that all the paterfamilias' powers, postestas, manus and mancipio, where originally a unified power in a very ancient stage of Roman legal history (see Gans 1821: 138ff). This view was adopted by Bonfante in order to build up his political theory of the Roman family, where manus, potestas and manicipium would originally have been expressions of the same singular power, which held a sovereign nature and would originally be called manus (see Bonfante 1963: 14ff). This theory became dominant during the twentieth century and with very important supporters (see, for instance, Corbett 1930=1979: 109ff; Düll 1944: 211ff; Mitteis 1908: 75; Wieacker 1940: 11; Söllner 1969: 12ff; Voci 1980: 420ff), although its predominance is long gone. Already Karlowa and Coli doubted the equivalence of manus and patria potestas (Karlowa 1865: 152ff; Coli 1951: 127ff). Gaudemet, undertaking a subsequent philological examination, established that the sources use manus mostly in relation to women, and never as an all-encompassing power in the way the political theory would predict (see Gaudemet 1979: $330 \mathrm{ff}$ ). From this point, Volterra saw a differentiation among the powers of the paterfamilias, with the expression potestas manus mancipium as its main feature. The extension of the powers would be different, depending on whether it is potestas (the strongest), manus or mancipium.

2 See Esmein 1886: 89ff; Düll 1944: 211ff; Voci 1980: 420ff; Wolff 1934: 317ff; Castello 1972: 97ff; Cremades \& Paricio 1983: 39ff).

3 We have discussed the matter at length elsewhere (see Amunátegui Perelló 2007: 61-153), therefore in this instance we will briefly state some of our conclusions on the matter. The texts that seem to give the power to a husband to kill his wife (Dionysius of Halicarnassus Ant Rom 2 252 1; and Aulus Gellius 1023 4) do not relate this power to manus. In fact, they both state that a man may kill his wife if he finds her committing adultery, which is exactly the opposite of the vitae necisque potestas. The vitae necisque potestas was not limited by pre-established cases or situations. It might have been limited by social standards, by tradition or by the nota censoriae, but not by specifically pre-determined cases. 
Our knowledge of manus is largely dependent on Gaius, from whom most of our information on the institution comes directly. This includes the expression "loco filiae", which is used only in his legal works. ${ }^{4}$ We will divide this work according to the subject treated when he mentions manus and mancipium in his Institutes. In this way, we will be able to appreciate the context properly and compare it with the powers that the pater holds over other persons alieni iuri.

\section{The division of people}

Gaius' book on persons opens with his well renowned division of free persons, on the one hand, and slaves, on the other. ${ }^{5}$ After dealing with slaves and freedmen, he incorporates yet another division of persons in his book, and this is the point at which his exposition regarding manus begins:

G 1 48: "Sequitur de iure personarum alia diuisio. nam quaedam personae sui iuris sunt, quaedam alieno iuri sunt subiectae." 1 49: "Sed rursus earum personarum, quae alieno iuri subiectae sunt, aliae in potestate, aliae in manu, aliae in mancipio sunt."

The exposition seems quite simple. There are two kinds of persons: independent persons (sui iuris); and those who are subject to the right of someone else (alieno iuri subiectae) and who may be subject to potestas, manus or mancipium. Following this division, he begins with those who are under potestas, namely the filifamiliae and slaves:

G 1 51: "Ac prius dispiciamus de iis, qui in aliena potestate sunt." 1 52: "In potestate itaque sunt serui dominorum. quae quidem potestas iuris gentium est." 1 55: "Item in potestate nostra sunt liberi nostri, quos iustis nuptiis procreauimus. quod ius proprium ciuium Romanorum est."

The symmetry in Gaius' descriptions is noteworthy. First, he describes who the persons are who may become subject to such power (servi in 151 and liberi in 155), and then he considers whether the power derives from the ius gentium (dominica potestas) or ius civile (patria potestas).

$4 \mathrm{G} 1111$ 4, 1114 5, 1 115b2, 1118 5, 1118 7, $113610,21393,2159$ 2, 3 32. Also in the Epitome 1521 . However, all references to manus were systematically removed from the Corpus, and therefore the expression might have been of wider use. From non-legal texts Seneca the Elder uses the expression, albeit in a text that does not seem to relate in any way to manus or the position of a wife (Seneca Controv 9515 9). Further use of it is by the late commentator Servius, who might have taken it from the same Institutes of Gaius: Servius In Georg 131 6: "coemptione vero atque in manum conventione, cum illa in filiae locum, maritus in patris veniebat, ut siquis prior fuisset defunctus, locum hereditatis iustum alteri faceret."

G 119 . 
As will become evident in the course of our analysis, Gaius never deviates from this division, ${ }^{6}$ reserving the word potestas only for slaves and liberi, and dealing separately with those who are under manus or mancipio, in juxtaposition to those under potestas. The use of the word potestas to describe the power exercised over slaves is quite common in Roman legal language. ${ }^{7}$ This assimilation is likely to have occurred long before the time of Gaius, or the Late Republic, when patria potestas was at its zenith. During the time of the Antonines, patria potestas was not an absolute power, for it had undergone a process of constant erosion over a period of several centuries. Probably during an earlier period the similarities were more evident. Two institutions may receive the same name when they look alike, but the similarity between patria potestas and slavery was not all that evident in either the Early Empire or the Late Republic. A common conceptualisation of slaves and descendants is likely when they both play a socio-economic role that is similar in a number of respects. This might have been the situation of slaves and sons during the Early Republic when they were the most important source of labour available to a pater for work required to be performed on the family land. Until the third century $\mathrm{BC}$, slavery was not an important phenomenon in Roman society ${ }^{8}$ and the weight of production in its smallholder economy lay in the nuclear family, sometimes aided by the external provision of work, either in the form of slave labour or through nexum or mancipium, which also brought "un-free" labour into the production unit. It was only during the Punic Wars that a massive movement of slave labour transformed the Italian economy, with the side effect of liberating the sons of the well-to-do from manual labour. As a collateral effect, during the second century $\mathrm{BC}$ the vitae necisque potestas became the exception, rather than the rule, ${ }^{9}$ although the power to kill one's descendants theoretically survived until the Antonines.

6 See Meylan 1970: 504.

7 See D $162 p r ; 12453 ; 141122$, among many others. We even have a direct quotation of the Edict in D 94212 regarding noxal actions: "Praetor ait: ' $\mathrm{Si}$ is in cuius potestate esse dicetur negabit se in sua potestate seruum habere: utrum actor uolet, uel deierare iubebo in potestate sua non esse neque se dolo malo fecisse, quo minus esset, uel iudicium dabo sine noxae deditione'." This is an important aspect for Cornil's theory on the Etruscan origin of potestas as a distinct power from the "Latin" institutions of manus and mancipium. See Cornil 1939: $405 \mathrm{ff}$.

8 Slavery seems to have appeared in Roman society under the later kings during the seventh century BC. See Franciosi 1959: 375; Franciosi 1992: 206; De Martino 1997a: 82-83; De Martino 1997b: 27-57. It seems to have become a major phenomenon only during the third century BC. On this subject, see Joshel 2010: 54f.

9 During the whole of the second century $\mathrm{BC}$ one can only find a handful of cases where this competency might be involved. These are the cases of D Junius Silano (Cicero De finibus 1 24; Livius Ab urbe condita 54; Valerius Maximus 58 3); Pontius Aufidianus (Valerius Maximus 61 3); Q Fabius Maximus (Valerius Maximus 6 15; Quintialinus Dec Mai 3 17; Orosius Adv Pag 5 16); the unnamed daughter of Atilius Philiscus (Val Max 616 ) and the son of M Scaurus (Lucius Ampelius Mem 19 10; Sex Iulus Frontinus Str 41 13; Val Max 58 4). Even in these cases, if the reason seemed unjustified, the pater might be punished, as happened to Fabius Maximus, who had to face exile. 
The same familiar structure is used to begin Gaius' commentary on manus:

G 1 108: " $<$ Nunc de his personis uideamus, quae in manu nostra sunt. quod $>$ et ipsum ius proprium ciuium Romanorum est." 1 109: "Sed in potestate quidem et masculi et feminae esse solent; in manum autem feminae tantum conueniunt."

Gaius states that manus is an institution that belongs to the ius civile. He compares it with potestas, saying that only women are subject to manus, while both men and women might be subject to potestas. Although this is not the only difference between these powers, the structure of Gaius' exposition is interesting.

Finally, he presents the power over sons in mancipio:

G 1 116: "Superest, ut exponamus, quae personae in mancipio sint." 1 117: "Omnes igitur liberorum personae, siue masculini siue feminini sexus, quae in potestate parentis sunt, mancipari ab hoc eodem modo possunt, quo etiam serui mancipari possunt." 118: "Idem iuris est in earum personis, quae in manu sunt: $<$ nam feminae a $>$ coemptionatoribus eodem modo possunt $<$ mancipari, quo liberi a parente possunt $>$, adeo $q u<\mathrm{i}>\mathrm{dem}$, $<$ ut quamuis ea sola $>$ apud coemptionatorem filiae loco sit. $<$ quae ei $>$ nupta sit, $<$ tamen $>$ nihilo minus etiam quae ei nup $<\mathrm{t}>\mathrm{a}$ non sit nec ob id filiae loco sit, ab eo mancipari possit." $1118 \mathrm{a}$ : " $<$ Sed $>$ plerumque solum et a parentibus et a coemptionatoribus mancipantur, cum uelint parentes coemptionatoresque $<\mathrm{ex}>$ suo iure eas personas dimittere, sicut inferius euidentius apparebit." 1 119: "Est autem mancipatio, ut supra quoque diximus, imaginaria quaedam uenditio: quod et ipsum ius proprium ciuium Romanorum est."

It is noteworthy that Gaius retains the same structure to describe the situation of filii in mancipio. He begins his commentary by saying that those who are under patria potestas may be the object of a mancipatio. He goes on to state that also those under manus can be the object of a mancipatio, but only to liberate them from manus. He concludes by identifying this institution as belonging to the ius civile.

We can say that Gaius follows a certain method in his division of persons. First, he indicates which power he is going to describe: potestas, manus or mancipium. Then he compares each with the one upon which he has previously commented: if it is manus, he compares it with potestas; if it is mancipio, he compares it with both manus and potestas, respectively, stating whether each belongs to the ius civile or ius gentium. Gaius seems to have three fixed categories in which he classifies persons without confusing them in any respect. To him, there are sharp distincions between potestas, manus and mancipio. 


\section{Ius vitae necisque according to Gaius}

The ius vitae necisque is a much-debated subject, about which we have written in general terms elsewhere. ${ }^{10}$ Therefore, in this instance, we will focus only on its treatment by Gaius in his Institutes.

G 1 52: "nam apud omnes peraeque gentes animaduertere possumus dominis in seruos uitae necisque potestatem esse ..."

Having defined potestas over slaves, Gaius states that the vitae necisque potestas was one of the central features of the power that masters held over their slaves. Although Gaius does not mention it, we know that descendants under the patria potestas were in the same position. ${ }^{11}$ However, his reluctance to mention the vitae necisque potestas in relation to descendants may be understood in light of the fact that, during Gaius' lifetime, the position of descendants under the patria potestas was the subject of debate and we know that Hadrian decided against a father who killed his son for no justified reason. ${ }^{12}$

Comparing the situation of descendants under patria potestas with that of persons under mancipio yields a sharp contrast:

G 1 141: "In summa admonendi sumus aduersus eos, quos in mancipio habemus, nihil nobis contumeliose facere licere; alioquin iniuriarum tenebimur."

We have studied elsewhere the origin of this disposition. ${ }^{13}$ It states that the son given in mancipio cannot be mistreated and, a fortiori, there is no vitae necisque potestas over him. The position of the wife in manu might have been similar, for there is no historical evidence of the vitae necisque potestas regarding her, at least from the perspective of her husband. ${ }^{14}$

10 See Amunátegui Perelló 2006: 37-143.

11 In fact, patria potestas could be defined as the power of life and death. In the formula of the adrogatio reported by Aulus Gellius, the question put to the comitia is whether they accept that a citizen enters under the vitae necisque potestas of another. See Aulus Gellius 519 9: "Eius rogationis verba haec sunt: Velitis, iubeatis, uti L. Valerius L. Titio tam iure legeque filius siet, quam si ex eo patre matreque familias eius natus esset, utique ei vitae necisque in eum potestas siet, uti patri endo filio est. Haec ita, uti dixi, ita vos, Quirites, rogo."

12 D 489 5: "Divus Hadrianus fertur, cum in venatione filium suum quidam necaverat, qui novercam adulterabat, in insulam eum deportasse, quod latronis magis quam patris iure eum interfecit: nam patria potestas in pietate debet, non atrocitate consistere."

13 See Amunátegui Perelló 2006: 37-143.

14 As we have already stated, the only two texts that authorise the husband to kill his wife (Dio Halicarnassus Ant Rom 2252 and Aulus Gellius 1023 4) restrict this to certain predefined cases (mainly adultery) and in no way connect these situations with manus. See Corbett 1930=1979: 127ff; Gaudemet 1979: 344; and Piro 1996: 152. 
To sum up, there seems to have been an important difference between those who were in potestate - whether they were slaves or descendants - and those who were in manu or in mancipio. The former were subject to the vitae necisque potestas, while the latter apparently were not.

\section{$4 \quad$ Emancipation according to Gaius}

It seems that it is always open to a paterfamilias to sever the bond of dependence. There are ample procedures available for the liberation of slaves, which we will not consider in depth. The same procedures may be used to liberate sons in mancipio:

G 1 138: "Ii, qui in causa mancipii sunt, quia seruorum loco habentur, uindicta, censu, testamento manumissi sui iuris fiunt."

The reason that Gaius provides for the same procedures being available to liberate slaves as well as those under mancipio is especially interesting: they would be servorum loco. This expression is analogous to that used to describe the position of the wife in manu, namely in loco filiae, and one may well draw parallels between them. In the same way that mancipatio can create fictional bondage that leaves the main features of citizenry unbroken, the position of a woman in manu was apparently fictional filiation of the same nature. It seems that each kind of potestas has a weaker, somewhat nebulous, parallel, which can create effects similar to it: mancipatio for the domenica potestas and manus for patria potestas.

As one might expect, the procedure to liberate a wife in manu is analogous to the one established to liberate a descendant:

G 1 137: "In manu autem esse mulieres desiunt isdem modis, quibus filiae familias potestate patris liberantur; sicut igitur filiae familias una mancipatione de postestate patris exeunt, ita eae quae in manu sunt una mancipatione desiunt in manu esse."

The passage above provides insights into the content of the expression "loco filiae". It highlights parallels between the way of exiting manus, on the one hand, and patria potestas, on the other. Just as those who were in mancipio could be liberated in the same way as slaves on the basis that they were servorum loco, the procedure to be followed in respect of a wife in manu had to be the same as that in respect of a filiafamiliae, for the former is loco filiae.

The information provided by Gaius does not cover the situation of persons who have entered manus through confarreatio, although we know that they had their own ceremony to exit manus (diffarreatio). However, this might have been due to the fact 
that confarreatio had only religious effects during the time of Gaius ${ }^{15}$ and therefore did not create the legal dependence that Gaius is addressing. Suffice it to say that, during Gaius' time, confarreatio was not really a possible way to enter manus. The effect is that stronger parallels may be drawn between the position of the daughter and the wife in manu.

An important difference between those who are subject to potestas and those who are in manus or mancipium is that the former cannot force the paterfamilias to liberate them, while the latter can:

G 1 137a: "nihil<o $>$ magis potest $<\mathrm{c}>$ ogere, quam et patrem. sed filia quidem nullo modo patrem potest cogere, etiam si adoptiua sit filia: haec autem $<$ uirum $>$ repudio misso proinde compellere potest, atque si ei numquam nupta fuisset."

G 1 140: "Quin etiam inuito quoque eo, cuius in mancipio sunt, censu libertatem consequi possunt, excepto eo, quem pater ea lege mancipio dedit, ut sibi remancipetur; nam quodam modo tunc pater potestatem propriam reseruare sibi uidetur eo ipso, quod mancipio recipit. ac ne is quidem dicitur inuito eo, cuius in mancipio est, censu libertatem consequi, quem pater ex noxali causa mancipio dedit, ueluti quod furti eius nomine damnatus est et eum mancipio actori dedit: nam hunc actor pro pecunia habet."

Both the son in mancipio and the wife in manu could, under certain circumstances, demand their own liberation. The wife could force her husband to emancipate her when they had divorced, as if they had never been married, that is to say, as if they had performed a coemptio fiduciae causa. On the other hand, the son in mancipio could force his acquirer to liberate him through the census. However, there were exceptions to this principle. First, if the pater, who sold the descendant, had established in a lege mancipio, perhaps through a nuncupatio, that his descendant should be re-mancipated to him, then this procedure should follow. Secondly, if the son had been surrendered as a consequence of a noxal action, then he could not force his own liberation.

15 In an endeavour to promote the use of confarreatio, any civil effects were removed during the Early Empire. See Tacitus Ann 4 16: "Sub idem tempus de flamine Diali in locum Servi Maluginensis defuncti legendo, simul roganda nova lege disseruit Caesar. nam patricios confarreatis parentibus genitos tres simul nominari, ex quis unus legeretur, vetusto more; neque adesse, ut olim, eam copiam, omissa confarreandi adsuetudine aut inter paucos retenta (pluresque eius rei causas adferebat, potissimam penes incuriam virorum feminarumque; accedere ipsius caerimoniae difficultates quae consulto vitarentur) et quoniam exiret e iure patrio qui id flamonium apisceretur quaeque in manum flaminis conveniret. ita medendum senatus decreto aut lege, sicut Augustus quaedam ex horrida illa antiquitate ad praesentem usum flexisset. igitur tractatis religionibus placitum instituto flaminum nihil demutari: sed lata lex qua flaminica Dialis sacrorum causa in potestate viri, cetera promisco feminarum iure ageret." 


\section{$5 \quad$ Appointment of a guardian}

After studying persons alieni iuris, in his first book of the Institutes, Gaius deals with guardianship:

G 1 142: "Transeamus nunc ad aliam diuisionem. nam ex his personis, quae neque in potestate neque in manu neque in mancipio sunt, quaedam uel in tutela sunt uel in curatione, quaedam neutro iure tenentur. uideamus igitur, quae in tutela, quae in curatione sint: ita enim intellegemus ceteras personas, quae neutro iure tenentur."

Again, Gaius draws a distinction between those who are under potestas, manus and mancipio, respectively. If manus and potestas were the same power, he would probably use the term potestas mancipioque or simply potestas to describe all three situations. He commences his exposition by explaining the method by which one may appoint a testamentary guardian for those who are subject to one's potestas:

G 1 144: "Permissum est itaque parentibus liberis, quos in potestate sua habent, testamen $<$ to tu $>$ tores dare: masculini quidem sexus inpuberibus, $<$ feminini uero inpuberibus puberibus $>$ que, $<$ uel $>$ cum nuptae sint. ueteres enim uoluerunt feminas, etiamsi perfectae aetatis sint, propter animi leuitatem in tutela esse."

The text serves as a clear indication that there is a difference between male and female descendants, because guardianship of women was established for life, even if they were married. A grandfather could appoint a guardian for his granddaughter when her natural father was no longer subject to the power of the paterfamilias, whether as a result of death or emancipation.

The position of a wife in manu is analogous to that of a daughter:

G 1 148: “<Vxori>, quae in manu est, proinde ac filiae, item nurui, quae in filii manu est, proinde ac nepti tutor dari potest."

As in the case of a granddaughter, the pater of the married filiusfamilias could appoint a testamentary guardian. This involves a commonly overlooked problem: if the paterfamilias passed away and the wife was in manu of the filius (as the text says), how could she be given a guardian, if manus and guardianship were incompatible? For the moment, we will simply point out the problem, which we will address below.

With respect to guardianship, there was an important difference between the situation of a wife in manu and a filia familias. The uxor in manu could be granted the right to choose a guardian (tutoris optio):

G 1 150: "In persona tamen uxoris, quae in manu est, recepta est etiam tutoris optio, id est ut liceat ei permittere, quem uelit ipsa, tutorem sibi optare."

It is not known when this emerged as a possibility in Roman legal history, but evidently it was possible at least during the second century $\mathrm{BC}$ since the freed 
woman Hispania Fecenia was given the right to choose a guardian as a reward for her participation in the criminal investigation regarding the bacchanalia:

Livius Ab urbe condita 3919 5: "utique Faeceniae Hispalae datio, deminutio, gentis enuptio, tutoris optio item esset, quasi ei uir testamento dedisset."

Apparently Livius is quoting the very text of the senatus-consultum, ${ }^{16}$ which seems evident from the technical language that he uses. However, the main elements of the institution, as described by Gaius some four hundred years later, are clear - the tutoris optio is granted as if it was established by his husband in a will (quasi ei vir testamento dedisset).

In the same way as the position of a wife in manu is assimilated to the position of a daughter, the position of a son in mancipio is equated to the position of a slave:

G 1 166: "Exemplo patronorum recepta est <et alia tutela, quae et ipsa legitima uocatur. nam si quis filium nepotemue aut pronepotem inpuberes, uel filiam neptemue aut proneptem tam puberes quam inpuberes alteri ea lege mancipio dederit, ut sibi remanciparentur, remancipatosque manumiserit, legitimus eorum tutor erit.>"

As we can see, those who are loco filiae and loco servorum are equated to the real daughter and the real slave as far as the appointment of a guardian was concerned. Both the wife in manu and the son in mancipio could be given a special kind of guardianship, the tutela fiduciaria:

G 1 166a: "Sunt et aliae tutelae, quae fiduciariae uocantur, id est quae ideo nobis competunt, quia liberum caput mancipatum nobis uel a parente uel a coemptionatore manumiserimus."

It is noteworthy that Gaius always makes a distinction in their position between those who are under potestas and those who are only in loco, thus avoiding any confusion between potestas, manus and mancipium.

\section{Acquisition of property}

Having concluded his first book on persons, Gaius' second commentary refers to res, subjects of law, where he observes the same division of the powers of the paterfamilias into potestas, manus and mancipio. Gaius states that the paterfamilias may acquire property through persons alieni iuris:

G 2 86: “Adquiritur autem nobis non solum per nosmet ipsos, sed etiam per eos, quos in potestate manu mancipioue habemus; item per eos seruos, in quibus usu $<$ mfructum $>$ habemus; item per homines liberos et seruos alienos, quos bona fide possidemus: de quibus singulis diligenter dispiciamus." 
In his third commentary he adds:

G 3 163: "admonendi sumus adquiri nobis non solum per nosmet ipsos, sed etiam per eas personas, quae in nostra potestate, manu mancipioue sunt."

According to Gaius we can acquire property through those who are subject to our potestas, manus and mancipio. In relation to potestas he includes only the slaves whom the pater owns. Those who are under usufructus he places in a separate category, although he says that we could acquire property through them in the same way as we aquire property through those under potestas. They seem to be equated to those whom we possess in good faith, but who are really free or who belong to someone else.

In the following section he focuses on those subject to the potestas of another, that is, descendants and slaves:

G 2 87: "Igitur < quod> liberi nostri, quos in potestate habemus, item quod serui nostri mancipio accipiunt uel ex traditione nanciscuntur siue quid stipulentur uel ex aliqualibet causa adquirunt, id nobis adquiritur: ipse enim, qui in potestate nostra est, nihil suum habere potest; et ideo si heres institutus sit, nisi nostro iussu hereditatem adire non potest; et si iubentibus nobis adierit, hereditas nobis adquiritur, proinde atque si nos ipsi heredes instituti essemus; et conuenienter scilicet legatum per eos nobis adquiritur."

Gaius tells us that we acquire, through persons subject to our potestas, not only property, but also possession:

G 2 89: "Non solum autem proprietas per eos, quos in potestate habemus, adquiritur nobis, sed etiam possessio; cuius enim rei possessionem adepti fuerint, id nos possidere uidemur; unde etiam per eos usucapio procedit."

Gaius deals next with the acquisition of property through persons who are subject to one of the powers that imitate potestas. Examples of such persons would be the wife in manu and sons in mancipio:

G 2 90: "Per eas uero personas, quas in manu mancipioue habemus, proprietas quidem adquiritur nobis ex omnibus causis sicut per eos, qui in potestate nostra sunt; an autem possessio adquiratur, quaeri solet, quia ipsa $<$ s $>$ non possidemus."

According to Gaius, we acquire property through such persons in the same way as we do through those subject to our potestas (slaves and descendants). However, there is an important difference: the possibility of acquiring possession is debatable because we do not possess such persons. This somewhat odd supposition has given scholars much food for thought. ${ }^{17}$ Gaius' reasoning is to some extent puzzling, especially

17 See Gaudemet 1979: 323ff; Volterra 1995a: 251ff; Zannini 1999: 3; Piro (1996): 47; or the rather controversial ideas of Cornil about possession and manus in Cornil 1939: 407ff, among many others. 
because one of the main differences between potestas, manus and mancipio appears to be this very feature. Although a measure of frustration may be felt on account of the paucity of information provided to us by Gaius, it may also be said that this is precisely what makes Roman law as interesting as it is for us. The same difference is apparent with regard to slaves under property and usufructus:

G 2 94: "De illo quaeritur: an per eum seruum, in quo usumfructum habemus, possidere aliqu $<\mathrm{am}>$ rem et usucapere possumus, quia ipsum non possidemus? per eum uero, quem bona fide possidemus, sine dubio et possidere et usucapere possumus. loquimur autem in utriusque person $<\mathrm{a}>$ secundum definitionem, quam proxume exposuimus; id est, si quid ex re nostra uel ex operis suis adquirant, id nobis adquiritur."

The reasoning is similar, and fortunately we know more about the position of a slave who is the subject of usufructus than we do about a wife in manu or a son in manicipio. Gaius, on this matter, adds:

G 2 91: "De his autem seruis, in quibus tantum usumfructum habemus, ita placuit, ut quidquid ex re nostra uel ex operis suis adquirunt, id nobis adquiratur; quod uero extra eas causas, id ad dominum proprietatis pertineat: itaque si iste seruus heres institutus sit legatumue quid ei aut donatum fuerit, non mihi, sed domino proprietatis adquiritur." 2 92: "Idem placet de eo, qui a nobis bona fide possidetur, siue liber sit siue alienus seruus: quod enim placuit de usufructuario, idem probatur etiam de bonae fidei possessore: itaque quod extra duas istas causas adquiritur, id uel ad ipsum pertinet, si liber est, uel ad dominum, si seruus est." 2 93: "Sed bonae fidei possessor cum usucepit seruum, quia eo modo dominus fit, ex omni causa per eum sibi adquirere potest. usufructuarius uero usucapere non potest; primum quia non possidet, sed habet ius utendi fruendi; deinde quia scit alienum seruum esse."

Regarding usufructus, the difference apparently lies in the fact that there are two persons who have rights over the slave, the nudus dominus and the usufructuarius, and therefore any property that the slave may acquire could go to either of them, depending on whether or not the property accrues by reason of his work. It may be argued that this situation is similar to that in which a pater has someone else's son in mancipio, in that there would also be two persons who hold a right over the son - his natural father, who does not lose potestas until the third time that he sells him, and the acquirer of the son in mancipio. On the other hand, in the case of the wife in manu, we do not have a parallel situation. What we do know is that marrying in manus breaks the agnatic family ties of the wife to her original paterfamilias. ${ }^{18}$ According to known population figures applicable to Roman society, ${ }^{19}$ this might be a rather rare case, for usually the low life expectancy in the Roman empire would prevent it. Another identifiable similarity between the position of the slave under usufructus

18 However, Voci and Russo Rugieri have put forward the possibility that even the wife in manu may still have links to her original family, at least for the repression of immoral acts. See Voci 1980: 421; and Russo Rugieri (1989-1990): 115.

19 See Saller 1994: 12ff. 
and the wife in manu is that the usufructuarius does not have the vitae necisque postestas over the slave, because by killing him he would destroy the property of the nudus dominus to whom he would therefore become liable. Would this then mean that the husband does not possess his wife in manu because he does not hold the vitae necisque potestas over her as he does over his descendants and slaves? Perhaps. However, this brings us to yet another problem. A wife in manu could not hold property because she had no patrimony. Therefore, if anything that she acquired did not belong to her husband, then who owned it? There are no clear-cut answers to these questions.

Finally, Gaius concludes his analysis by pointing out that no person under potestas, manus or mancipium can perform an in iure cessio:

G 2 96: "In summa sciendum est his, qui in potestate manu mancipioue sunt, nihil in iure cedi posse; cum enim istarum personarum nihil suum esse possit, conueniens est scilicet, ut nihil suum esse in iure uindicare possint."

The reason for this is easy to understand. None of the abovementioned persons has patrimony and therefore they cannot vindicate anything. As a welcome change, there does not appear to be any doubt in relation to this aspect.

\section{$7 \quad$ Acquisition of universalities}

Having dealt with singular acquisitions, Gaius analyses universal acquisitions. He equates manus with the adoption of a person sui iuris:

G 2 98: "Si cui heredes facti sumus siue cuius bonorum possessionem petierimus siue cuius bona emerimus siue quem adoptauerimus siue quam in manum ut uxorem receperimus, eius res ad nos transeunt."

The reasoning is simple. Through the capitis deminutio that manus implies, the property of the wife became the patrimony of the husband (as dowry ${ }^{20}$ ) or his pater (if he himself is alieno iuris). A detailed explanation is given in the third commentary of Gaius:

G 3 83: "Etenim cum pater familias se in adoptionem de $<$ dit $>$ mulierue in manum conuenit, omnes eius res incorporales et corporales, quaeque ei debitae sunt, patri adoptiuo coemptionatoriue adquiruntur exceptis his, quae per capitis deminutionem pereunt, quales sunt ususfructus, operarum obligatio <libertorum $>$, quae per iusiurandum contracta est, et $<$ lites contestatae $>$ legitimo iudici<0 $>$." 3 84: "Ex diuerso quod is debu<it, qui se in $>$ adoptionem dedit quaeue in manum conue $<$ nit, non $>$ transit ad coemptionatorem aut ad patrem adoptiuum, nisi si hereditarium aes alienum $\mathrm{f}<\mathrm{uerit}$; de eo $>$ enim, quia ipse pater adoptiuus aut coemptionator heres fit, directo tenetur iure, $\mathrm{i}<\mathrm{s}$ uero, qui $>$ se adoptandum dedit, quaeue in manum conuenit, desinit esse heres; de eo uero, quod proprio nomine eae

20 Cicero Top 23 3: "Ab effectis rebus hoc modo: Cum mulier viro in manum convenit, omnia quae mulieris fuerunt viri fiunt dotis nomine." 
personae debuerint, licet neque pater adoptiuus teneatur neque coemptio- nator $<$ et ne $>$ ipse quidem, qui se in adoptionem ded $<$ it, uel ipsa $>$, quae in manum conuenit, maneat obligatus obligata $<$ ue $>$, quia scilicet per capitis diminutionem liberetur, tamen in eum eamue utilis actio datur rescissa capitis deminutione, et, si aduersus hanc actionem non defendantur, quae bona eorum futura fuissent, si se alieno iuri non subiecissent, uniuersa uendere creditoribus praetor permittit."

Of the categories of persons who could eventually have entered into the dependence of the paterfamilias, these were the only two that could have held patrimony and, therefore, they are studied together. This is unusual because, as we have already seen, Gaius normally analyses manus and mancipium together.

\section{Succession mortis causa}

Persons who were subject to the potestas of the paterfamilias could become successors to the pater's inheritance. The slaves - who became heredes necessarii - had to be liberated as designated by the will, and they could not reject the inheritance. It was the praetor who granted these heredes the ius abstinendi in order that they could avoid loss that the succession could possibly entail. Gaius proceeds to explain that the descendants who became sui iuris upon the death of the pater - who were called heredes sui et necessarii - were also not permitted to reject the inheritance. Gaius, following his traditional order of treatment, commences his exposition with the heirs who were subject to the potestas of the deceased paterfamilias:

G 2 152: "Heredes autem aut necessarii dicuntur aut sui et necessarii aut extranei." 2 153: "Necessarius heres est seruus cum libertate heres institutus, ideo sic appellatus, quia siue uelit siue nolit, omni modo post mortem testatoris protinus liber et heres est." 2 156: "Sui autem et necessarii heredes sunt uelut filius filiaue, nepos neptisue ex filio <et $>$ deinceps $\mathrm{ce}<\mathrm{te}>\mathrm{ri}$, qui modo in potestate morientis fuerunt: sed uti nepos neptisue $\mathrm{su}<\mathrm{u}>\mathrm{s}$ heres sit, non sufficit eum in potestate aui mortis tempore fuisse, sed opus est, ut pater quoque eius uiuo patre suo desierit suus heres esse aut morte interceptus aut qualibet ratione liberatus potestate; tum enim nepos neptisue in locum sui patris succedunt."

Persons who were subject to the potestas of another were governed by the particular rules that were applicable. Therefore, the wife in manu viri will become a heres sui et necessaria, while those under mancipio will be heredes necessarii. Following his usual method, Gaius begins with persons under manus and thereafter he analyses the position of persons under mancipio:

G 2 159: "Idem iuris (that of the daughters under potestas) est et $<$ in $>$ uxoris persona, quae in manu est, quia filiae loco est, et in nuru, quae in manu filii est, quia neptis loco est." 2 160: "Quin etiam similiter abstinendi potestatem facit praetor etiam ei, qui in causa [id est mancipato] mancipi $<\mathrm{i}>$ est, $<\mathrm{si}>$ cum libertate heres institutus sit, cum necessarius, non etiam suus heres sit, tamquam seruus." 
In relation to heritage, Gaius once again draws a parallel between persons who are under potestas and persons who occupy the place of a person under potestas. The situation of the wife in manu is equated to that of a daughter and those who are under mancipio are in a position analogous to that of actual slaves, at least for hereditary matters. The rules concerning the situation of the heredes sui et necessarii are set out in some detail thereafter, in the third commentary:

G 3 1: " $<$ Intestatorum hereditates ex lege xii tabularum primum ad suos heredes pertinent>." 3 2: " $<$ Sui autem heredes existimantur liberi, qui in potestate morientis fuerunt, ueluti filius filiaue, nepos neptisue ex filio, pronepos proneptisue ex nepote filio nato prognatus prognataue. nec interest, utrum naturales sint liberi an adoptiui. ita demum tamen nepos neptisue et pronepos proneptisue suorum heredum numero sunt, si praecedens persona desierit in potestate parentis esse, siue morte id acciderit siue alia ratione, ueluti emancipatione; nam si per id tempus, quo quis moriatur, filius in potestate eius sit, nepos ex eo suus heres esse non potest. idem et in ceteris deinceps liberorum personis dictum intellegemus $>$." 3 : " $<$ Vxor quoque, quae in manu eius, qui moritur, est, ei sua heres est, quia filiae loco est. item nurus, quae in filii manu est, nam et haec neptis loco est. sed ita demum erit sua heres, si filius, cuius in manu fuerit, cum pater moritur, in potestate eius non sit. idemque dicemus et de ea, quae in nepotis manu matrimonii causa sit, quia proneptis loco est $>$."

Gaius once again follows his usual method of separate treatment of the rules pertaining to persons under potestas and persons who are only in that position (in loco), in this case, those under manus. The passage highlights an important difference. Regarding grandchildren under potestas, Gaius states that they could become heredes sui et necesarii, given that after the grandfather died their natural father (the filiusfamilias of the pater) was no longer under the potestas of the paterfamilias. Later, while analysing the position of the daughter-in-law in manu - who would be in the position of a granddaughter - Gaius tells us that the same rules applied to her situation, given that her husband was no longer in the potestas of the pater.

The son could exit the potestas of the pater by reason of either his own death or his emancipation. Where the natural son died, the position seemed to be straightforward, but where the son was emancipated, some questions could be raised. If the son was emancipated, did the wife in manu remain under the power of his paterfamilias? Or did her status change in line with that of her husband? The case is also explained in the Collatio:

Collatio 162 3: "Uxor quoque, quae in manu est [ei cuius in manu est] sua heres est, quia filiae loco est: item nurus quae in filii manu est, nam et haec neptis loco est. Sed ita demum erit sua heres [si] filius, cuius in manu sit cum pater moritur, in potestate eius non sit. Idemque dicimus et de ea, quae [in] nepotis manu matrimonii causa sit, quia proneptis loco est."

In principle, after the emancipation of the natural father, his descendants remained in the power of the grandfather, who was still his paterfamilias, and they became sui iuris after the latter's death. Therefore, the position in relation to a daughter-in-law in manu could be the same. As we have seen, in G 1 148, Gaius informs us that the 
father-in-law was entitled to appoint a guardian for his daughter-in-law. Because manus and guardianship were incompatible - on the basis that guardianship implied a patrimonial capacity that manus excluded - we should conclude that the emancipation of the son terminated his manus relationship with his wife, who remained under the dependence of her father-in-law, in the same way as the grandchildren did. ${ }^{21}$

Regarding disinheritance, Gaius equates the position of adopted sons with that of the wife in manu on the basis that they both invalidate the will in a similar way to that in which the postumi do: ${ }^{22}$

G 2 138: "Si quis post factum testamentum adoptauerit sibi filium aut per populum eum, qui sui iuris est, aut per praetorem eum, qui in potestate parentis fuerit, omni modo testamentum eius rumpitur quasi agnatione sui heredis." 2 139: "Idem iuris est, si cui post factum testamentum uxor in $\mathrm{manu}<\mathrm{m}>$ conueniat, uel quae in manu fuit, nubat: nam eo modo filiae loco esse incipit et quasi sua."

Equating the two situations seems justified because through adoption the pater legally acquired an heir (who was a postumus with respect to the will) in the same way as, through manus, he acquired a person who occupied the same hereditary position as his own daughter. Volterra used this fragment to propose that the wife in manu would enter into her husband's potestas through the conventio in manu. ${ }^{23}$ However, an examination of the passage in its context shows clearly that this is not what Gaius maintains. He uses different wording in his exposition of the situation with respect to an adopted son and the wife in manu, respectively. When dealing with the former, Gaius specifically mentions the word potestas, while he seems to treat the latter's position as if she was loco filiae. Gaius does not state that the wife in manu is in potestate, and it would be only by forcing the text that one could arrive at such a conclusion, which would seem to contradict Gaius' entire exposition. Once Gaius has divided the powers of the paterfamilias into potestas, manus and mancipio, he never merges them again, but he treats them separately in each situation in which he must explain a matter pertinent to them. Manus seems merely to imitate potestas, as the son in mancipio was in a position in which parallels could be drawn with a situation of slavery, although only in some respects. In this respect, Volterra's conclusion is untenable.

However, there is a third text in which the situation of the wife in manu and the adoptive son are equated. It occurs in the treatment of the rights of inheritance that the ex-master (patronus) could hold in the succession to the rights of his freedmen. According to the information given by Gaius, the inheritance of the patronus varied

21 Piro (at 1996: 93ff) proposes the contrary. The main problem with her hypothesis is that she does not seem to take into account the fact that guardianship and manus are incompatible with each other.

22 See Düll 1944: 207ff.

23 Volterra 1995a: 251ff. 
through time. During the time of the Twelve Tables, he could be passed over in the testamentary succession and was called to the inheritance only in case of intestacy, if the freedman had no sui heredes (descendants, adoptive sons or daughters or a wife in manu). This position would have changed due to the praetor granting bonorum possession contra tabulas to the patronus if the freedman did not leave to the patronus an inheritance equivalent to one half of his (the freedman's) goods. In any event, in the case of intestacy, if the freedman did not leave natural descendants and only had an adoptive son or a wife in manu, the praetor would grant him bonorum possessio:

G 3 41: "si uero intestatus moriatur suo herede relicto adoptiuo filio <uel $>$ uxore, quae in manu ipsius esset, uel nuru, quae in manu filii eius fuerit, datur aeque patrono aduersus hos suos heredes partis dimidiae bonorum possessio. prosunt autem liberto ad excludendum patronum naturales liberi, non solum quos in potestate mortis tempore habet, sed etiam emancipati et in adoptionem dati, si modo aliqua ex parte heredes scripti $<$ sint aut praeteriti con>tra tabulas testamenti bonorum possessionem ex edicto petierint ..."

This is a disposition created to favour the position of the patronus by diminishing the importance of the agnatic ties, which the law creates, in contrast to blood ties. It left intact the position of the natural descendants, but impaired the position of the wife in manu and the adoptive son. This seems to be a disposition that went against the original spirit of Roman civil law and had an exceptional character. Regarding the nurus in manu, the observation made above tended also to accord with this understanding of the situation. Although her husband could have been emancipated, she still fell under the dependence of his former paterfamilias.

\section{Obligations}

In his third commentary ( $388 \mathrm{ff}$ ), Gaius deals with obligations: how they are constituted; their validity; and how they may be extinguished. Regarding stipulatio, he explains that a person alieno iuri subiecta could not acquire an obligation towards his paterfamilias, something which seems evident since the qualities of debtor and creditor would be confused in the same patrimony. After explaining the problem, Gaius states that neither slaves nor persons who were in mancipio, nor a daughter, nor persons in manu, could acquire any obligation by stipulatio, not only to the power holder, but also to any other person:

G 3 104: " $<$ Praeterea $>$ inutilis est stipulatio, si ab eo stipuler, qui iuri meo subiectus est, item $\mathrm{si}$ is a me stipuletur. seruus quidem et qui in mancipio est et $\langle\mathrm{fi}>\mathrm{l}<\mathrm{ia}$ familia $>$ s et quae in manu est, non solum ipsi, cuius iuri subiecti subiectaeue sunt, obligari non possunt, sed ne alii quidem ulli."

To go into the possible reasons for omitting the filiusfamilias from this enumeration would fall outside of the parameters of this study, devoted as it is to Gaius' exposition of manus and mancipio. However, a reason may be that the filiusfamilias could hold patrimony separately by virtue of his peculium castrense, but we leave this question 
for a separate study. ${ }^{24}$ What is relevant in this context is that Gaius does not use the word manus or potestas to refer to persons who are under the dependence of the paterfamilias. The technical expression that he uses is iuri subiecti. In other words, as far as concerns legal terminology, neither potestas nor manus are allencompassing expressions that may be used, as many scholars have assumed, to describe the different, nuanced, situations of persons under the dependence of the pater. ${ }^{25}$ Later, in the text explaining "adstipulatio", Gaius points to an anomaly in the institution which he calls a singular right:

G 3 114: "in hoc autem iure quaedam singulari iure obseruantur. nam adstipulatoris heres non habet actionem. item seruus adstipulando nihil agit, qui ex ceteris omnibus causis stipulatione domino adquirit. idem de eo, qui in mancipio est, magis placuit; nam et is serui loco est. is autem, qui in potestate patris est, agit aliquid, sed parenti non adquirit, quamuis ex omnibus ceteris causis stipulando ei adquirat; ac ne ipsi quidem aliter ac $<$ tio $>$ conpetit, quam si sine kapitis diminutione exierit de potestate parentis, ueluti morte eius aut quod ipse flamen Dialis inauguratus est. eadem de filia familias et quae in manu est, dicta intellegemus."

Again, we will not go into the full depth of the problem, ${ }^{26}$ but we will limit our comments to the formal aspects of the reasoning. One can appreciate Gaius' division between, on the one hand, slaves and persons who are under mancipio, and on the other, a filiafamilias in relation to which he draws parallels with the situation of the wife in manu. The observation may be made that Gaius uses the expression "loco" to extend a traditional solution to a specific problem to situations that were not originally envisaged by or included in it. The concept loco serves an interpretative function in jurisprudence, permitting the creation of new solutions for unresolved cases. Nevertheless, the conceptual separation between potestas and its more nuanced imitations is retained.

\section{Actio furti and iniuriae}

Once Gaius has concluded his analysis of contractual liability, he explains tort law. In this section he deals with the case of furtum of free people under the potestas of the paterfamilias:

G 3 199: "Interdum autem etiam liberorum hominum furtum fit, uelut si quis liberorum nostrorum, qui in potestate nostra sint, siue etiam uxor, quae in manu nostra sit, siue etiam iudicatus uel auctoratus meus subreptus fuerit."

According to Gaius, the paterfamilias can bring an action of furtum for his son in potestate, his wife in manu, the iudicatus and a gladiator under a salary (auctoratus), the two falling outside the purview of our study. ${ }^{27}$ Again, Gaius treats the situation of the wife in manu and the son in mancipio separately, a pattern that is observed

24 For a detailed study, see Scherillo 1930: $203 \mathrm{ff}$.

25 See $n 1$.

26 On the matter see Scherillo 1930: 219ff.

27 See Watson 1971: 146; Treggiari 1969: 141. 
consistently throughout his work. Although a slave could obviously be subject to furtum, the text does not include this situation, perhaps because it deals specifically with cases when the actio furti can be brought in relation to free people. This may be the reason for the omission of the son in mancipio, for his situation is usually equated with that of a slave.

Regarding the iniuria, the situation is a bit more complicated:

G 3 221: "Pati autem iniuriam uidemur non solum per nosmet ipsos, sed etiam per liberos nostros, quos in potestate habemus, item per uxores nostras, quamuis in manu nostra $<$ non $>$ sint; itaque si ueluti filiae meae, quae Titio nupta est, iniuriam feceris, non solum filiae nomine tecum agi iniuriarum potest, uerum etiam meo quoque et Titii nomine."

Although reconstruction of the text is still being debated, especially regarding the matter of whether, after "in manu nostra", there should be a "non", ${ }^{28}$ some comments may be made. In principle, the victim of an iniuria was the one who held the actio iniurarium, but the pater of the victim under potestas and the husband, even if he had no manus, also held the action. For this reason, this yields a somewhat awkward outcome. One would expect that only the husband could have sued when he held manus, because his wife would then have been under his dependence, but that, if the marriage was without manus, only the paterfamilias could have sued because she remained a filiafamilias. Some editors prefer to omit the "non" and would have the text read that the husband could sue only when he held manus. While this would accord with what is known about the agnatic family system, it does not make much sense in the context of the following example that Gaius provides: A daughter was married to Titus and someone commited an iniuria to her. Gaius expressly states that both the father and the husband would have had an action. If the traditional system applied, then only the pater (if she was under potestas) or the husband (if she was under manus) would have had an action, but the text says that both of them did. In addition, the word used by Gaius to describe the marriage is "nupta", which seems to be linked with sine manu marriage in Gaius' vocabulary. ${ }^{29}$ This may be viewed as something of an exception in that it appears to extend the protection to the victim. It may be the result of a development in the concept of iniuria, to permit wider protection of the victim, based on personal ties rather than power relations. ${ }^{30}$

28 We follow the Seckel-Kuebler reconstruction of the text (see Seckel \& Kuebler 1938). However, some editions read "item per uxores nostras [cum in manu nostra sint]" (Ad ex: Manthe 2004). Very recently, Cursi has defended this first reading in a very seductive way, relating it to the development of the praetorian iniuria (see Cursi 2012: 255-288).

29 He uses this very same word to describe the process of acquisition of manus through usus. In G 1111 he expressly states that a wife should stay nupta for a year in order to enter the manus of her husband: G 1 111: "Usu in manum conueniebat, quae anno continuo nupta perseuerabat; quia enim uelut annua possessione usu capiebatur, in familiam uiri transibat filiaeque locum optinebat. itaque lege duodecim tabularum cautum est, ut si qua nollet eo modo in manum mariti conuenire, ea quotannis trinoctio abesset atque eo modo cuiusque anni usum interrumperet. sed hoc totum ius partim legibus sublatum est, partim ipsa desuetudine obliteratum est."

30

Cursi 2012: 255-288. 
On the other hand, regarding slaves, the servus is not considered to be a victim of iniuriae, save for the case that through offending him, an iniuria to the master is intended:

G 3 222: "Seruo autem ipsi quidem nulla iniuria intellegitur fieri, sed domino per eum fieri uidetur; non tamen iisdem modis, quibus etiam per liberos nostros uel uxores iniuriam pati uidemur, sed ita, cum quid atrocius commissum fuerit, quod aperte in $<$ con $>$ tumeliam domini ieri uidetur, ueluti si quis alienum seruum uerberauerit, et in hunc casum formula proponitur; at si qui $<\mathrm{s}>$ seruo conuicium fecerit uel pugno eum percusserit, non proponitur ulla formula nec temere petenti datur."

Iniuria against a slave attracted no liability, except if by acting against the slave the author intended to offend the master. The position in relation to persons under mancipio was very different, because, as we saw earlier, they could use an action for iniuria even against the holder of the mancipio. Gaius does not say if the mancipium holder could use the iniuria action when the offence inflicted against the son in mancipio was also intended against him. It was possible, but the position is unclear.

What is interesting is that iniuria apparently broke the assimilation between persons who were under potestas and persons who were in loco. Manus did not seem relevant in this context, and even the husband of the wife sine manu could have used the action. A son in mancipio was subject to an entirely different regime to that which applies to a slave. It is when studying the subject of iniuriae that the difference between being under potestas, on the one hand, and on the other, being under one of its imitations, in loco filiae or servorum, becomes evident.

\section{Actiones fictae}

Sometimes the praetor, when dealing with alieni iuri, granted actions as if capitis deminutio had never occurred. The praetor's aim is to prevent persons from avoiding liability by becoming subject to the dependence of another. This could have been the case in relation to an adrogatus and also the wife in manu, because both might have held patrimony before the capitis deminutio when the adoption or the convention in manu was performed. The praetor gives the following actio ficta:

G 4 38: "Praeterea aliquando fingimus aduersarium nostrum capite deminutum non esse. nam si ex contractu nobis obligatus obligataue sit et capite deminutus deminutaue fuerit, uelut mulier per coemptionem, masculus per adrogationem, desinit iure ciuili debere nobis, nec directo intendi potest sibi dare eum eamue oportere; sed ne in potestate eius sit ius nostrum corrumpere, introducta est contra eum eamue actio utilis rescissa capitis deminutione, id est, in qua fingitur capite deminutus deminutaue non esse."

The similarity, as Volterra points out, lies in the fact that in both cases the person who had entered the dependence of a paterfamilias held patrimony before the capitis deminutio. ${ }^{31}$

31 Volterra 1995a: 251ff. 


\section{Actiones noxales}

Elsewhere we have treated at length the situation of the wife in manu and a son in mancipio with respect to actiones noxales ${ }^{32}$ and therefore we simply refer, in this instance, to the systematic method of Gaius' analysis of the subject. First, Gaius explains the situation in relation to persons under potestas (the son and the slave) with respect to penal actions:

G 4 75: "Ex maleficio filiorum familias seruorumque, ueluti si furtum fecerint aut iniuriam commiserint, noxales actiones proditae sunt, uti liceret patri dominoue aut litis aestimationem suffer $<r>e$ aut noxae dedere. erat enim iniquum nequitiam eorum ultra ipsorum corpora parentibus dominisue damnosam esse."

Thereafter, Gaius explains the situation regarding persons who are in their position, or "place" (in loco), in other words, those under manus and mancipio:

G 4 80: "Haec ita de his personis, quae in potestate $<$ sunt $>$, siue ex contractu siue ex $<$ ma $>$ leficio earum $<$ controuer $>$ sia $<$ si $>$ t. quod uero ad $<\mathrm{e}>\mathrm{a}<\mathrm{s}>$ personas, quae in manu mancipioue sunt, ita ius dicitur, ut cum ex $<$ contr $>$ actu earum ag $<\mathrm{a}>$ tur, nisi $a b$ eo, cuius iuri subiectae sint, in solidum defendantur, bona, quae earum $\mathrm{f}<\mathrm{u}>$ tura forent, si $\mathrm{e}<$ ius $>$ iuri subiectae non essent, ueneant. sed cum resciss $<$ a capitis deminutione cum iis $>$ imperio continenti iud $<\mathrm{i}>\mathrm{c}<\mathrm{io}>$ agit $<$ ur $>$, ***,

Sadly, the text is lost as Gaius is about to begin with actiones ex delicto. Nevertheless, the jurist again follows his own division between those who are under potestas and those who are under manus and mancipio.

\section{Conclusion}

We have witnessed how, throughout Gaius' entire work in which he discusses alieni iuri, he maintains a division between those who are under potestas - that is to say, slaves and descendants - and those who are only in their place, namely the wife in manu and the son in mancipio. We observed that the expression potestas is used to describe only the situation of descendants and slaves and that in not even a single text does Gaius use this word to refer to the wife in manu or a son in mancipio.

The dependence to which a slave and a filiusfamilias were subject was apparently similar in many respects. Both the filiusfamilias and the slave were subject to the vitae necisque potestas; could be surrendered for noxal actions; were heredes necessarii; provided a means by which the pater could acquire possession and property; and were prevented from forcing the pater to liberate them. Their respective positions were, however, apparently different when one considers the procedures that the pater might have used to free them; the effects that the astipulatio could produce; and by virtue of the fact that the filiifamilias were also heredes sui, while the slaves were not.

32 See Amunátegui Perelló 2008: 205-236. 
Equating the descendants and the slaves seems rather odd if one considers the prevailing social realities during the Late Republic and Early Empire. During the Late Republic a steady decline in the practical intensity of patria potestas led to a progressive dissolution of its most brutal aspects. In fact, during the Late Republic the exercise of the vitae necisque potestas was somewhat problematic and, if not backed by the authority of the Senate ${ }^{33}$ or a consilium amicorum, could lead to social ostracism..$^{34}$ During the Early Empire, the practice was suppressed for any practical purpose. All things considered, equating descendants and slaves in this context seems to fit more appropriately with the archaic social reality of Rome when the main working forces at the pater's disposal were relatively few slaves and his own descendants.

On the other hand, the words manus and mancipium - which seem to date from earlier times - are used to describe the powers that are to some extent shaded, or nuanced, equivalents of potestas. The wife in manu is loco filiae, while the son in mancipio is loco servorum. The comment may be made that the main difference between potestas and its imitations was the intensity of the personal powers that the pater could exercise. The wife in manu and the son in mancipio do not seem to have been under vitae necisque potestas, both of them could enjoy fiduciary guardianship and neither of them was under the possession of the pater. They could compel the pater to liberate them. Another point of significance is that the powers that may be exercised over all of the persons subject to potestas tend to be different to those that may be exercised in respect of persons under manus or mancipium. In this respect we could reduce Gaius' division into a dual partition, with, on one side, persons under potestas and, on the other, those under manus (or mancipium). Manus would not be equivalent to potestas, as the traditional theory holds ${ }^{35}$ nor would manus generate potestas, as Volterra proposed. ${ }^{36}$ The difference between potestas and manus is substantial, probably originating in Early Roman law, and is embedded in social realities that are beyond the scope of this modest work.

\section{Abstract}

This article studies the meaning of the expression in "loco filiae" that Gaius uses to describe the position of the wife that has undergone a conventio in manum. Its aim is

33 As in the case of Lucius Gellius, who judged his son, with the whole Senate acting as a consilium, during the last century of the Republic (Valerius Maximus 59 1). See Kunkel 1966: 22; Volterra 1995b: 133; Bauman 1984: 1290.

34 This was the case of Quintus Fabius Maximus, who killed his son for conducting himself with dubious chastity. He was accused by the tribunus plebis and was thereafter exiled. See Valerius Maximus 61 5; Quintilian Decl Mai 3 17; Orosius Adv Pag 5 16. Scholarship has been prolific on the case, see Rabello 1979: 12; Harris 1986: 84ff; Albanese 1991: 360; Kaser 1938: 6; Volterra 1995b: 143; Thomas 1981: 663.

35 Mitteis 1908: 75; Wieacker 1940: 11; Söllner 1969: 12ff.

36 Volterra (1995a): 251ff. 
to ascertain whether or not manus, potestas and mancipium were equivalent powers, in the time of Gaius, by identifying, in particular, institutions which reflect disparate regulation of each.

\section{Bibliography}

Albanese, Bernardo (1991) "Note sull'evoluzione storica del ius vitae ac necis" Scritti Giuridici vol 1 (Palermo): 343-366

Amunátegui Perelló, Carlos Felipe (2006) “Origen de los poderes del pater familias I" Revista de Estudios Histórico-Jurídicos 38: 37-143

Amunátegui Perelló, Carlos Felipe (2007) “Origen de los Poderes del pater familias II" Revista de Estudios Histórico-Jurídicos 39: 51-163

Amunátegui Perelló, Carlos Felipe (2008) "La entrega noxal de sujetos in manu mancipioque" Iura. Rivista internazionale di diritto romano e antica 56: 205-236

Bauman, Richard A (1984) "Family law and Roman politics" Sodalitas, scritti in onore di Antonio Guarino (Jovene): 1283-1300

Bonfante, Pietro (1963) Corso di diritto romano, Diritto di famiglia (Milano)

Castello, Carlo (1972) Studi sul diritto familiar e gentilizio romano (Roma)

Coli, Ugo (1951) “Regnum” Studia et Documenta Historiae et Iuris: 1-168

Corbett, Percy Ellwood (1930=1979) The Roman Law of Marriage (Oxford)

Cornil, Georges (1939) “Du mancipium au dominium” Festschrift Koschaker zum 60 Geburtstag vol 1 (Weimar): 404-444

Cremades, Ignacio \& Paricio, Javier (1983) Dos et virtus, devolución de dote y sanción a la mujer romana por sus malas costumbres (Barcelona)

Cursi, Floriana (2012) "Pati iniuriam per alios (Gai 3 22-222)" Bulletino dell'Istituto di Diritto Romano "Vittoria Scialoja”: 255-288

De Martino, Francesco (1997a) "Clienti e condizioni materiali in Roma arcaica” Diritto economia e societá nel mondo romano vol 3 (Napoli): 82-83

De Martino, Francesco (1997b) "Intorno all'origine della schiavitù a Roma" Diritto economia e societá nel mondo romano vol 3 (Napoli): 130-161

Düll, Rudolf(1944) “Studien zur Manusehe" Festschrift Leopold Wenger zu seinem 70 Geburtstag (München): 203-223

Esmein, Adhémar (1886) Mélanges d'histoire du droit et de critique, Droit Romain (Paris)

Franciosi, Gennaro (1959) "Res mancipi e res nec mancipi" Labeo: Rassegna di diritto romani 5: 370-390

Franciosi, Gennaro (1992) Famiglia e persone in Roma antica (Torino)

Gans, Eduard (1821) Scholien zum Gaius (Berlin)

Gaudemet, Jean (1979) “Observations sur la manus” Études de Droit Romain 3 (Jovene): 191-223

Harris, William (1986) “The Roman father's power of life and death" Studies in Roman Law in Memory of A. Arthur Schiller (Leiden): 81-96

Joshel, R Sandra (2010) Slavery in the Roman World (Cambridge) 
Karlowa, Otto (1865) Römische Rechtsgeschichte (Leipzig)

Kaser, Max (1938) “Der Inhalt der Patria Potestas" Zeitschrift der Savigny Stiftung Rom Abt 58: $62-87$

Kunkel, Wolfgang (1966) “Das Konsilium im Hausgericht” Zeitschrift der Savigny Stiftung Rom Abt 83: 219-251

Manthe, Ulrich (2004) Gaius Institutiones (Darmstadt)

Meylan, Philipe (1970) "Origin de la formule in potestate manu mancipiove" Ètudes à Jean Macqueron (Aix-en-Provence): 503-514

Mitteis, Ludwig (1908) Romische Privatrecht (Leipzig)

Piro, Isabella (1996) "Riflessioni in tema di in manu filii esse" Iura. Rivista internazionale di diritto romano e antica 47: 93-160

Rabello, Alfredo M (1979) Effetti personali della patria potestas (Milano)

Russo Rugieri, Carmela (1989-1990) "Qualche osservazione in tema di ius occidendi e lex Iulia de adulteriis" Bulletino dell'Istituto di Diritto Romano "Vittorio Scialoja": 31-32; 93-120

Saller, Richard (1994) Patriarchy, Property and Death in the Roman Family (Cambridge)

Scherillo, Gaetano (1930) "Sulla stipulazione del servus e del filiusfamilias" Studii in onore di Bonfante vol 4 (Milano): 203-241

Seckel, E \& Kuebler, B (1938) Gai Institutionum commentarii quattuor (Leipzig)

Söllner, Alfred (1969) Zur Vorgeschichte und Funktion der actio rei uxoriae (Wien)

Thomas, Yaron (1981) Parricidium Mélanges de l'École française de Rome (Rome): 643-715

Treggiari, Susan (1969) Roman Freedmen during the Late Republic (Oxford)

Voci, Pascuale (1980) "Storia della patria potestas da Augusto a Diocleziano" 31 Iura. Revista internazionale di diritto romano e antica: $37-100$

Volterra, Edoardo (1995a) "Nuove ricerche sulla conventio in manum" Scritti giuridici vol 3 (Napoli): 199-216

Volterra, Edoardo (1995b) "Il preteso tribunal domestico" Scritti giuridici vol 2 (Napoli): 127-177

Watson, Alan (1971) Roman Private Law Around 200 B.C. (Edinburgh)

Wieacker, Franz (1940) Hausgenossenschaft und Erbeinsetzung (Leipzig)

Wolff, Hans Julius (1934) "Das iudicium de moribus und sein Verhältnis zur action rei uxoriae" Zeitschrift der Savigny Stiftung Rom Abt 54: 315-320

Zannini, Pierluigi (1999) "Ancora su usu in manum convenire" Labeo: Rassegna di diritto romano: $412-420$ 